\author{
MARCIN BIRT \\ ORCID: 0000-0003-2668-0393 \\ Uniwersytet Wrocławski
}

\title{
Dekret sierpniowy PKWN z 1944 roku jako instrument legalizacji władzy komunistycznej w Polsce
}

\section{Wstęp}

Wskutek sukcesów militarnych Armii Czerwonej nad III Rzeszą oraz późniejszych ustaleń między USA, ZSRR i Wielką Brytanią podjętych na konferencjach w Jałcie i Poczdamie ziemie wchodzące w skład powojennego państwa polskiego dostały się do sowieckiej strefy wpływów. Implikowało to liczne, często rewolucyjne, zmiany nie tylko o charakterze społeczno-politycznym i ekonomicznym, lecz także prawnym, co oznaczało między innymi recepcję do polskiego systemu prawnego sowieckich wzorców.

Zasadniczym celem niniejszego opracowania jest postawienie i obrona tezy, iż dekret Polskiego Komitetu Wyzwolenia Narodowego z dnia 31 sierpnia 1944 roku o wymiarze kary dla faszystowsko-hitlerowskich zbrodniarzy winnych zabójstw i znęcania się nad ludnością cywilną i jeńcami oraz dla zdrajców Narodu Polskiego (tekst pierwotny: Dz.U. z 1944 r. Nr 4, poz. 16-17 z późn. zm., dalej: dekret lub dekret sierpniowy) oraz jego praktyka orzecznicza stanowią przykład wykorzystania prawa w celu legalizacji władzy komunistycznej i jej legitymizacji — władzy pozbawionej szerszego społecznego poparcia, opartej wyłącznie na przemocy, zwłaszcza sile militarnej Armii Czerwonej oraz sowieckiego aparatu represji.

Po 1989 roku problematyka rozrachunków z totalitaryzmem sowieckim stała się przedmiotem wielu polskich opracowań naukowych. Odmiennie sytuacja przedstawia się $\mathrm{w}$ zakresie analogicznych badań obejmujących problematykę niemieckiego narodowego socjalizmu (nazizmu). Przyczyn takiego stanu rzeczy 
można upatrywać w swoistym spiętrzeniu publikacji związanych z problematyką zbrodni hitlerowskich, powstałych w okresie Polskiej Rzeczypospolitej Ludowej (PRL), nierzadko nasyconych treściami ideologicznymi, a przez to często trudnymi do zaakceptowania w nowym nurcie dyskursu naukowego. Nie oznacza to jednak, że problematyka zbrodni hitlerowskich została w piśmiennictwie polskim zupełnie zarzucona. Pojawiały się publikacje stanowiące istotny wkład w badania nad niemieckim narodowym socjalizmem, które - co wymaga szczególnego podkreślenia — były wolne od typowych przed 1989 roku zabarwień ideologicznych, korespondujących z założeniami ustrojowymi PRL.

Pomimo zgromadzonego materiału badawczego poza wzmożonym zainteresowaniem polskiej doktryny pozostawało jednak zagadnienie legitymizacji narzuconej z zewnątrz (czynniki: polityczne i militarne ZSRR w ramach tak zwanego porządku jałtańskiego) władzy komunistycznej w drodze nadzwyczajnego prawodawstwa karnego. Pod pojęciem „władza komunistyczna” na potrzeby przedmiotowego opracowania należy rozumieć podporządkowane politycznie Związkowi Radzieckiemu (ZSRR) i od niego zależne ośrodki władzy, instalowane na ziemiach polskich wraz z wkroczeniem Armii Czerwonej oraz towarzyszących jej sowieckich formacji represyjnych: NKWD (Ludowego Komisariatu Spraw Wewnętrznych) oraz kontrwywiadu wojskowego (SMERSZ). Pierwszym z nich był Polski Komitet Wyzwolenia Narodowego (PKWN) z Edwardem Osóbką-Morawskim na czele, która to instytucja miała stanowić emanację podporządkowanej interesom politycznym ZSRR władzy komunistycznej w Polsce.

„Nowa władza” rzeczywiście stanowiła sowiecką ekspozyturę polityczną w Polsce. Wpływ na ten stan rzeczy miało wiele czynników, których wyczerpujące przedstawienie, a tym bardziej omawianie, leży poza zakresem tematycznym niniejszego opracowania. Dlatego też zasadne będzie ograniczenie się do wskazania najważniejszych spośród nich:

— brak szerszego poparcia społecznego Komunistycznej Partii Polski w okresie międzywojennym;

- marginalne znaczenie polskiej partyzantki komunistycznej w walce z okupacyjnym aparatem policyjno-represyjnym III Rzeszy;

- przewaga w społeczeństwie polskim postaw lojalnościowych wobec polskiego rządu emigracyjnego (,rządu londyńskiego”) i brak powszechnej akceptacji dla rewolucyjnej przebudowy stosunków społeczno-politycznych w Polsce według wzorców sowieckich;

— daleka nieufność, często przechodząca w jawną wrogość, wobec sowieckich czynników politycznych po ujawnieniu wiosną 1943 roku przez Niemców mogił polskich oficerów pomordowanych przez sowieckie NKWD (zbrodnia katyńska) i związanego z tym zerwania stosunków dyplomatycznych między polskim rządem emigracyjnym a ZSRR.

Zainstalowani w Polsce komuniści, świadomi tego, że gwarantem ich władzy jest militarne wsparcie Armii Czerwonej oraz sowieckich formacji represyjnych, 
poszukiwali sposobu zjednania sobie polskiego społeczeństwa, trwale okaleczonego tragicznymi skutkami realizacji w okupowanej przez Niemców Polsce hitlerowskiej polityki masowego rasowego terroru i ludobójstwa. Sytuacja ta stwarzała możliwość przedstawienia się komunistycznej władzy w Polsce jako jedyny, skuteczny „depozytariusz krzywd”, który z całą surowością prawa odpowiednio ukarze hitlerowskich zbrodniarzy i proniemieckich zdrajców.

Truizmem jest stwierdzenie, że społeczeństwo bardziej podporządkowuje się władzy, którą akceptuje, przyjmując jej aksjologię polityczną ${ }^{1}$. Jak zauważa Piotr Winczorek, istnieją pewne formuły — argumenty legitymizacyjne — właściwe dla konkretnej władzy. Wśród nich wyróżnia między innymi:

— kierowanie się szlachetnymi ideałami,

— realizowanie „naszego” (społecznego) interesu,

— odnoszenie aktualnych sukcesów,

— wyłączny charakter zwierzchnictwa w danej sytuacji ${ }^{2}$.

Niewątpliwie okoliczności te występowały wspólnie w odniesieniu do Polskiego Komitetu Wyzwolenia Narodowego. Umiejętne początkowe maskowanie retoryki komunistycznej (według wzorca sowieckiego), eksponowanie czynnika narodowego (polskiego) przy wsparciu sowieckiej potęgi militarnej, połączone $\mathrm{z}$ dążeniem do przedstawiania się w roli sprawiedliwego sędziego hitlerowskich oprawców i zdrajców stanowiły działania obliczone na efekt - pozyskanie rzeczywistego poparcia społecznego.

Jednakże, jak każda władza totalitarna, również PKWN dostrzegł możliwość wykorzystania prawodawstwa wymierzonego przeciwko zbrodniarzom hitlerowskim także przeciwko swoim rzeczywistym lub urojonym wrogom, a zwłaszcza polskiemu podziemiu niepodległościowemu. Propaganda komunistyczna usiłowała zrównać je z hitlerowskimi kolaborantami i antypolskimi zdrajcami. Takie działanie miało też na celu legalizację ,nowej władzy” w oczach polskiego społeczeństwa przez oczernienie politycznych wrogów jako stygmatyzowanych hitleryzmem, co było obliczone na utratę przez nich społecznego zaufania, a tym samym pomocy.

Niniejszy artykuł zawiera charakterystykę regulacji materialnoprawnych dekretu sierpniowego oraz przedstawienie rozwiązań proceduralnych warunkujących praktyczne aspekty jego zastosowania. Zamieszczono w nim ponadto prezentację wybranych procesów sądowych przedstawicieli hitlerowskiej machiny terroru, a także polskiego podziemia niepodległościowego, zasługujących w tym ostatnim wypadku na miano zbrodni sądowych. Ze względu na ograniczony objętościowo zakres publikacji zagadnienie to zostanie jedynie zasygnalizowane, jako że zainteresowany czytelnik bez trudu odnajdzie fachową literaturę na ten temat.

1 Więcej na ten temat zob. L. Dubel et al., Elementy nauki o państwie i polityce, Warszawa 2011, s. 32 n.

2 Ibidem, s. 35. 
Na wybranym przykładzie dodatkowo zostaną omówione nastroje społeczne, które - pomijając niewątpliwie dostrzegalne zaangażowanie propagandowo-ideologiczne relacji prasowych - towarzyszyły procesom sądowym prowadzonym przez polski wymiar sprawiedliwości wobec przedstawicieli hitlerowskiego aparatu terroru.

\section{Dekret sierpniowy — ogólna charakterystyka}

Dekret sierpniowy, określany w piśmiennictwie jako „przepisy odwetowe”3, miał być prawnym instrumentem do ukarania zbrodniarzy hitlerowskich i ich kolaborantów działających w okresie II wojny światowej. Odznaczał się między innymi wyjątkową represyjnością oraz mocą retroaktywną (wszedł w życie 13 września 1944 roku, obejmując penalizacją czyny popełnione przed datą jego obowiązywania). Regulacja ta, współcześnie z pewnością kontrowersyjna, pozostawała jednak w zgodności z późniejszymi: statutem Międzynarodowego Trybunału Wojskowego oraz zasadami procesu norymberskiego 4 .

Dekret sierpniowy wzorowany był na prawodawstwie sowieckim i opierał się na rozwiązaniach radzieckiego dekretu z dnia 19 kwietnia 1943 roku o odpowiedzialności za szpiegostwo i ludobójstwo na jeńcach i ludności cywilnej5 Ostateczny kształt normatywny omawiany akt prawny przyjął w wyniku nowelizacji z 1946 roku. Przepisy art. 1 dekretu stanowiły, że:

Art. 1. Kto, idąc na rękę władzy państwa niemieckiego lub z nim sprzymierzonego:

1. brał udział w dokonywaniu zabójstw osób spośród ludności cywilnej albo osób wojskowych lub jeńców wojennych,

2. przez wskazanie lub ujęcie działał na szkodę osób ze względów politycznych, narodowościowych, wyznaniowych lub rasowych poszukiwanych lub prześladowanych przez władze, podlega karze śmierci ${ }^{6}$.

Z kolei nowelizacja dokonana w 1946 roku, dotycząca przepisów art. 2 dekretu, rozszerzała zakres przedmiotu ochrony, którym objęto również ,polskie osoby prawne". Po nowelizacji art. $3 \mathrm{w}$ brzmieniu nadanym powołaną nowelizacja głosił, iż:

Kto, wyzyskując warunki wytworzone przez wojnę, wymuszał świadczenia pod groźbą wywołania prześladowań przez władze państwa niemieckiego lub z nim sprzymierzonego albo w inny sposób działał na szkodę osób poszukiwanych lub prześladowanych przez te władze, podlega karze więzienia na czas nie krótszy od lat 3 lub więzienia dożywotniego.

${ }^{3}$ P. Kładoczny, Prawo jako narzędzie represji w Polsce Ludowej (1944-1956), Warszawa 2004, s. 176.

4 Ibidem, s. 177.

5 Więcej zob. A. Lityński, Ze studiów nad początkami wojskowego prawa karnego PRL, [w:] Problemy prawa karnego, t. 21, red. K. Marszał, Katowice 1995, s. 25-26.

6 Dz.U. z 1946 r. Nr 69, poz. 376. 
Zupełnie nową regulacją były natomiast przepisy art. 4 dekretu, w myśl których:

Art. $4 \S 1$. Kto brał udział w organizacji przestępczej, powołanej lub uznanej przez władze państwa niemieckiego lub z nim sprzymierzonego albo przez zrzeszenie polityczne, które działało w interesie państwa niemieckiego lub z nim sprzymierzonego, podlega karze więzienia od lat 3 lub dożywotnio albo karze śmierci.

$\S 2$. Za organizację przestępczą w rozumieniu $\S 1$ uważa się grupę lub organizację:

a) która ma na celu zbrodnie przeciwko pokojowi, zbrodnie wojenne lub zbrodnie przeciwko ludzkości,

b) która mając inny cel, zdąża do osiągnięcia go przez popełnianie zbrodni określonych w pkt a).

$\S 3$. Przestępstwem jest zwłaszcza udział:

a) w niemieckiej narodowo-socjalistycznej partii robotniczej (National Sozialistische Deutsche Arbeiter Partei — NSDAP) na wszelkich stanowiskach kierowniczych,

b) w sztafetach ochronnych (Schutzstaffeln - SS),

c) w tajnej policji państwowej (Geheime Staatspolizei - Gestapo),

d) w służbie bezpieczeństwa (Sicherheist Dienst - SD).

Zmiany redakcyjne wprowadzone nowelizacją z 1946 roku dostosowywały brzmienie przepisów art. 4 dekretu do narodowosocjalistycznych organizacji uznanych za przestępcze w myśl prawa międzynarodowego. Omawiana regulacja szła jednak dalej — posługując się pojęciem stwarzającym daleko idące możliwości interpretacyjne - ,zrzeszenia politycznego, które działało w interesie państwa niemieckiego" - dawała nowej władzy politycznej na ziemiach polskich oręż do zwalczania wszelkich jej wrogów, pod zarzutem członkostwa w takim właśnie „zrzeszeniu" 7 .

Wśród innych zasługujących na szczególne uwzględnienie regulacji normowanych przez dekret warto wskazać: wyłączenie możliwości powołania się na stan wyższej konieczności (art. 3 w wersji pierwotnej z 1944 roku, złagodzony w brzmieniu nadanym po nowelizacji z 1946 roku - art. 5 § 2 dekretu), wyłączenie możliwości warunkowego zawieszenia wykonywania kary (w redakcji dekretu po nowelizacji z 1946 roku — jego art. 8) oraz obligatoryjną konfiskatę mienia w całości (pierwotna wersja dekretu przewidywała możliwość orzeczenia kary konfiskaty mienia wobec małżonka i dzieci skazanego — art. $5 \S 1$ dekretu). Sprawcy, których oskarżono o popełnienie czynów stypizowanych jako przestępstwa określone dekretem, poddano jurysdykcji specjalnych sądów karnych.

Rozważając kwestie ratio legis dekretu oraz kolejnych jego nowelizacji, zasadnicze znaczenie należy przypisać:

- wskazywanemu dążeniu do surowego ukarania zbrodniarzy hitlerowskich realizujących na ziemiach polskich ludobójczą politykę niemieckiego okupanta;

7 Piotr Kładoczny wskazuje na praktykę orzeczniczą ówczesnych polskich sądów, których orzeczenia odpowiadały nieudowodnionej, uznawanej jednak przez władze komunistyczne teorii o współpracy Armii Krajowej z Niemcami — zob. idem, op. cit., s. 182-183. 
— nieostremu zakreśleniu znamion poszczególnych przestępstw ujętych w dekrecie, co stwarzało możliwość wykorzystania represyjnej regulacji do celów innych niż ukaranie zbrodniarzy hitlerowskich oraz ich kolaborantów;

- dążenie do uczynienia państwa polskiego „depozytariuszem krzywd” ofiar hitlerowskiego bezprawia, uprawnionego do dokonaniu w ich imieniu sprawiedliwego odwetu 8 .

Zasadne jest przedstawienie przykładów praktyki orzeczniczej stosowania przepisów dekretu, w szczególności przez pryzmat wykładni znamion typizujących ujęte tam przestępstwa. Dotyczy to w szczególności wybranych aspektów wykładni znamion:

— zbrodni określonych przepisami art. 1 dekretu,

— przestępstwa „wymuszania świadczeń” (,szmalcownictwa”) określonego przepisami art. 3 dekretu,

- czynu polegającego na udziale w organizacji przestępczej stypizowanego $\mathrm{w}$ art. 4 dekretu (z uwagi na ich precedensowy w polskim prawie karnym charakter).

Termin „pójścia na rękę” stanowił zupełne novum w polskiej terminologii prawnokarnej. Sąd Najwyższy wyraził pogląd, że zbrodnia stypizowana w art. 1 dekretu nie wymaga szczególnej umyślności czy celowej tendencji „pójścia na rękę" władzy niemieckiej, przyjmując w tym zakresie objęcie omawianego znamienia zamiarem (bezpośrednim lub ewentualnym) sprawcy ${ }^{9}$. W taki też sposób utrwaliła się linia orzecznictwa, a „pójście na rękę” doznawało konkretyzacji w okolicznościach danego stanu faktycznego. Przyjmowano, iż występuje ono między innymi w takich sytuacjach, jak służba w uznawanej przez Niemców polskiej Policji Państwowej (,grantowa policja”) bądź sprawowanie funkcji strażnika w obozie pracy lub kapo w obozie koncentracyjnym ${ }^{10}$.

Przepisy art. 1 dekretu używały znamienia „brania udziału w zabójstwach”. Określenie to należy rozumieć szerzej niż pozbawienie życia człowieka, stanowiące zbrodnię stypizowaną chociażby w polskim Kodeksie karnym z 1932 roku $^{11}$ (art. 225). Orzecznictwo sądowe przyjęło za obowiązujący pogląd, iż „branie udziału w zabójstwach” obejmuje między innymi orzekanie w ramach niemieckiego, okupacyjnego „policyjnego sądu doraźnego” (tak zwany Standgericht) - uznawanego nie za organ wymiaru sprawiedliwości, a narzędzie eksterminacji ludności polskiej — oraz wykonywanie ferowanych przez te sądy

\footnotetext{
8 Ibidem, s. 183.

9 Uzasadnienie wyroku Sądu Najwyższego z dnia 8 kwietnia 1948 roku, sygn. akt Wa K 101/48, Zb.Orz. 103/48.

10 Zob. uzasadnienia wyroków: Sądu Najwyższego z dnia 8 sierpnia 1950 roku, sygn. akt K 454/50, „Państwo i Prawo” 1950, nr 11, s. 192-193; Sądu Apelacyjnego we Wrocławiu z dnia 14 stycznia 1950 roku, sygn. akt III K 82/50, APW-Prok.Woj. 857/15, s. 7; Sądu Apelacyjnego we Wrocławiu z dnia 23 czerwca 1950 roku, sygn. akt III K 82/50, APW-Prok.Woj. 863/15, s. 21.

11 Rozporządzenie Prezydenta Rzeczypospolitej Polskiej z dnia 11 lipca 1932 roku Kodeks karny (Dz.U. z 1932 r. Nr 60, poz. 571).
} 
wyroków śmierci; również eskortowanie ujętych osób na miejsce straceń przez członków okupacyjnych formacji policyjnych było uznawane za „udział w zabójstwach" w rozumieniu przepisów art. 1 dekretu ${ }^{12}$. Określając więc relację między przepisami art. 1 dekretu a regulacją na gruncie art. 225 k.k. z 1932 roku należy przyjąć, iż pierwsza z nich wyłączała stosowanie przepisów „kodeksowych” na zasadzie specjalności (lex specialis derogat legi generali). Argumentowano ponadto, że celem dekretu była zupełna kryminalizacja udziału w hitlerowskiej machinie śmierci, różniąca się zasadniczo od aktu umyślnej fizycznej przemocy nad człowiekiem, skutkującego pozbawieniem go życia ${ }^{13}$.

Regulacja na gruncie art. 2 dekretu, której celem było ściganie oraz karanie przede wszystkim „szmalcowników” (szantażystów wymuszających korzyści majątkowe od ukrywających się Żydów pod groźbą wydania ich Niemcom), nie wymagała już od sprawcy działania w ramach „,pójścia na rękę” władzom okupacyjnym. Do przypisania znamienia umyślności wystarczyła motywacja rabunkowa sprawcy, chęć działania we własnym interesie. W przeciwieństwie do zbrodni stypizowanych w art. 1 dekretu czyn z art. 2 nie doczekał się rozwiniętej linii orzeczniczej. Uprawniony jest w tej kwestii prezentowany w piśmiennictwie pogląd, że wpływ na to miała postawa wymiaru sprawiedliwości Polskiego Państwa Podziemnego, które konsekwentnie ścigało i surowo karało - w tym śmiercią szantażystów (,szmalcowników”) ${ }^{14}$.

Definicję organizacji przestępczej, w której członkostwo było kryminalizowane na podstawie przepisów dekretu, zawierał art. $4 \S 2$ tego aktu prawnego. $\mathrm{W}$ ten sposób dostosowano polskie prawodawstwo karne do wyroku norymberskiego, uznającego wszystkie wymienione w dekrecie organizacje za przestępcze. Treść art. 4 dekretu stanowiła konsekwencję przystąpienia przez Polskę 25 września 1945 roku do porozumienia londyńskiego z 8 sierpnia 1945 roku oraz stanowiącej jego integralną część Karty Międzynarodowego Trybunału Wojskowego (Trybunału Norymberskiego) ${ }^{15}$. Wprawdzie związanie Rzeczypospolitej Polskiej porozumieniem londyńskim wymuszało skorelowanie orzecznictwa sądów polskich z odpowiednim orzecznictwem międzynarodowym, jednak polska judykatura uznawała za organizacje przestępcze $\mathrm{w}$ rozumieniu stosowanych regulacji dekretu również takie, które nie były jako takie postrzegane w myśl nie tylko prawa międzynarodowego, lecz także — literalnie — przepisów dekretu.

12 Zob. uzasadnienie wyroku Sądu Najwyższego z dnia 13 lutego 1948 roku, sygn. akt Kr K 33/48, Zb.Orz. 44/48; uzasadnienie wyroku Sądu Najwyższego z dnia 29 sierpnia 1948 roku, sygn. akt Wa K 338/48, DPP 1948 nr 9, s. 47-48.

13 Zob. uzasadnienie wyroku Sądu Najwyższego z dnia 25 maja 1949 roku, sygn. akt K/478/49, „Państwo i Prawo” 1949, nr 9-10, s. 196.

14 Tak: A. Pasek, Przestęstwa okupacyjne w polskim prawie karnym z lat 1944-1956, Wrocław 2002, s. 97.

15 Dz.U. z 1947 r. Nr 63, poz. 367. 
U schyłku lat czterdziestych XX wieku w orzecznictwie pojawił się pogląd, iż Armia Krajowa (AK) była „organizacją zdradziecką, przestępczą, idącą na rękę władzy okupacyjnej państwa niemieckiego"16. Ten szokujący obecnie pogląd argumentowano tym, że AK, ,stawiała sobie za zadanie zabijanie działaczy tudzież niszczenie organizacji lewicowych i demokratycznych walczących z okupantem oraz ich zwolenników" ${ }^{17}$. Wymaga jednak podkreślenia, że taka kwalifikacja miała charakter oceny politycznej dokonanej w konkretnej sprawie; nawet w okresie polskiego stalinizmu nie posunięto się do oficjalnego uznania AK za „organizację przestępczą".

Opierając się na danych Wydziału Statystycznego Ministerstwa Sprawiedliwości, ustalono, że do 1 stycznia 1948 roku na podstawie dekretu skazano 9463 osoby, w tym:

- 1055 - na karę śmierci,

- 981 - na karę dożywotniego więzienia lub więzienia powyżej 10 lat,

— 7427 - na karę więzienia do lat $10^{18}$.

\section{Praktyka orzecznicza: Najwyższy Trybunał Narodowy, specjalne sądy karne i polskie sądy powszechne}

Z dekretem sierpniowym należy łączyć kolejny dekret PKWN z dnia 12 września 1944 roku o specjalnych sądach karnych dla spraw zbrodniarzy faszystowsko-hitlerowskich ${ }^{19}$. Początkowo utworzono trzy specjalne sądy karne (dalej też: sądy specjalne), działające przy istniejących już sądach apelacyjnych, aby następnie powiększyć ich liczbę do ośmiu (z siedzibami w: Gdańsku, Toruniu, Wrocławiu, Poznaniu, Lublinie, Katowicach, Krakowie z Wydziałem Zamiejscowym w Rzeszowie oraz w Łodzi z Wydziałami Zamiejscowymi w Warszawie i Białymstoku) ${ }^{20}$. W parze z wyjątkowym charakterem stosowanych przed sądami specjalnymi przepisów prawa materialnego szedł charakter przepisów proceduralnych. Do ich najbardziej charakterystycznych cech należy zaliczyć:

— jednoinstancyjność postępowania,

- przyjęcie formuły dochodzenia, a nie śledztwa celem przedsądowego zgromadzenia materiału dowodowego,

16 Uzasadnienie wyroku Sądu Najwyższego z dnia 1 października 1948 roku, sygn. akt Kr K 1254/48, „Państwo i Prawo” 1948, Nr 12, s. 151.

17 Ibidem.

18 Zob. A. Pasek, op. cit., s. 172 i podana tam literatura.

19 Dz.U. z 1944 r. Nr 4, poz. 21.

20 Sąd Specjalny Karny w Rzeszowie w 1945 roku funkcjonował samodzielnie przy sądzie apelacyjnym w Rzeszowie. Wydziały Zamiejscowe w Warszawie i Białymstoku specjalnego Sądu Karnego dla Okręgu Sądu Apelacyjnego w Warszawie z siedzibą w Lodzi utworzono na początku 1946 roku. Więcej zob. Z. Biegański, Kara śmierci w orzecznictwie Specjalnych Sąów Karnych w Polsce (1944-1946), „Echa Przeszłości” 2004, nr 5, s. 182. 
— ogłaszanie wyroków natychmiast po naradzie składu orzekającego (miały one charakter ostateczny i prawomocny),

— podleganie przez oskarżonych obowiązkowemu aresztowi.

Skazani na śmierć mogli wnosić o zastosowanie wobec nich prawa łaski przez Prezydenta Krajowej Rady Narodowej, natomiast cech dwuinstancyjności należy upatrywać w ustanowieniu w styczniu 1946 roku Najwyższego Trybunału Narodowego ${ }^{21}$. Sądy specjalne orzekały w składach: sędzia i dwóch ławników wyznaczonych przez Prezydium Krajowej Rady Narodowej spośród kandydatów przedstawionych przez wojewódzkie rady narodowe, właściwe ze względu na siedzibę sądów. Należy podkreślić, że o doniosłości urzędu sędziowskiego w sądzie specjalnym świadczyło zrównanie jego statusu z sędzim sądu apelacyjnego ${ }^{22}$.

Najwyższy Trybunał Narodowy miał wyjątkowy status w strukturze wymiaru sprawiedliwości ${ }^{23}$, który przejawiał się między innymi w powierzeniu kognicji rozpoznawania spraw karnych przestępców zgodnie z treścią alianckich porozumień międzynarodowych oddanych do dyspozycji organów ścigania państw, w których popełnili swoje zbrodnicze czyny. W praktyce przed Najwyższym Trybunałem Narodowym rozpatrywano sprawy ekstradowanych do Polski oskarżonych lub sprawujących funkcje kierownicze w aparacie niemieckiego okupanta ${ }^{24}$. O randze Najwyższego Trybunału Narodowego świadczy ponadto jego status zrównany z pozycją Sądu Najwyższego - jego Prezesem był Pierwszy Prezes Sądu Najwyższego.

Wyposażony w nadzwyczajne uprawnienia i wyjątkowy status system polskiego sądownictwa specjalnego (rozumianego jako specjalne sądy karne oraz Najwyższy Trybunał Narodowy) mógł przystąpić do sprawowania wymiaru sprawiedliwości zgodnie ze swoim zadaniem - rozliczenia zbrodni popełnionych przez przedstawicieli niemieckich władz okupacyjnych oraz ich kolaborantów na ziemiach polskich w okresie II wojny światowej. Przed Najwyższym Trybunałem Narodowym przeprowadzono siedem procesów — ogółem skazano 49 zbrodniarzy hitlerowskich, w tym 31 na karę śmierci. Wśród skazanych przez Najwyższy Trybunał Narodowy należy w szczególności wymienić:

— byłego gauleitera i namiestnika Kraju Warty Arthura Greisera - skazany na karę śmierci przez powieszenie; wyrok wykonano publicznie na stoku poznańskiej cytadeli 21 lipca 1946 roku;

— byłego szefa rządu i zastępcę generalnego gubernatora Hansa Franka doktora Józefa Bühlera - skazany na karę śmierci przez powieszenie; wyrok wykonano 22 sierpnia 1948 roku w krakowskim więzieniu Montelupich;

21 Dz.U. z 1946 r. Nr 59, poz. 326-327.

22 A. Murzynowski, J. Rezler, Wymiar sprawiedliwości w Polsce w latach 1944-1970. Ustawodawstwo, organizacja i działalność, Warszawa 1972, s. 24.

23 Z. Biegański, op. cit., s. 185.

${ }^{24}$ Ibidem, s. 186. 
— byłego komendanta obozu koncentracyjnego w Oświęcimiu Rudolfa Hössa — skazany na karę śmierci przez powieszenie; wyrok wykonano 16 kwietnia 1947 roku na terenie obozu, którym kierował — podkreślenia wymaga to, iż termin egzekucji nie został podany do publicznej wiadomości, gdyż ludność Oświęcimia chciała dokonać samosądu i zlinczować Hössa;

- byłego gauleitera Okręgu Gdańsk-Prusy Zachodnie Alberta Forstera skazany na karę śmierci przez powieszenie; wyrok wykonano 28 lutego 1952 roku w warszawskim więzieniu mokotowskim;

- członków załogi niemieckiego obozu koncentracyjnego w Oświęcimiu, w tym: Artura Liebehenschela — następcę Rudolfa Hössa na stanowisku komendanta obozu koncentracyjnego w Oświęcimiu oraz komendanta obozu KL Majdanek; Hansa Aumeiera — zastępcę komendanta obozu koncentracyjnego w Oświęcimiu; Marię Mandel - kierowniczkę obozu kobiecego w Oświęcimiu - wszyscy zostali skazani na karę śmierci przez powieszenie, a wyroki zostały wykonane.

Spośród sądzonych przed Najwyższym Trybunałem Narodowym członków załogi obozu koncentracyjnego w Oświęcimiu w procesie trwającym od 24 listopada do 16 grudnia 1947 roku łącznie 23 oskarżonych zostało skazanych na karę śmierci, 6 - na karę dożywotniego więzienia, 10 - na karę długoterminowego więzienia, tylko jedna osoba została uniewinniona ${ }^{25}$.

Procesy przed specjalnymi sądami karnymi (poza Najwyższym Trybunałem Narodowym) również odznaczały się surowością wydawanych wyroków. Należy jednak pamiętać, iż oskarżonymi w tych postępowaniach były w zdecydowanej większości osoby w pełni zaangażowane w funkcjonowanie nazistowskiej machiny śmierci. Mając na uwadze ograniczenia objętościowe niniejszego opracowania, zasadne będzie ograniczenie się do wskazania szczególnie istotnych — z punktu widzenia okoliczności procesu — dwóch postępowań: przed Specjalnym Sądem Karnym w Lublinie, w którym oskarżonymi byli członkowie załogi KL Majdanek, oraz przed Specjalnym Sądem Karnym w Gdańsku — tu oskarżonymi byli członkowie załóg niemieckich obozów na Pomorzu.

W pierwszym ze wskazanych procesów (trwającym od 27 listopada do 2 grudnia 1944 roku) na ławie oskarżonych zasiedli między innymi: Herman Vögel, Teodor Schmolen, Anton Ferens i Wilhelm Gerstenmeier. Sąd potwierdził swoją kognicję dla oskarżonych, negując to, jakoby byli żołnierzami podlegającymi sądownictwu wojskowemu — uznał ich za zbrodniarzy i morderców, którzy nie pełnili czynności związanych z prowadzeniem działań wojennych. Zostali skazani na karę śmierci, a wyroki wykonano przez powieszenie 3 grudnia 1944 roku $^{26}$.

25 Ibidem, s. 187.

26 E. Kobierska-Motas, Ekstradycja przestępców wojennych do Polski z czterech stref okupacyjnych Niemiec 1946-1950, cz. 2, Warszawa 1992, s. 11-12. 
W drugiej sprawie, przed Specjalnym Sądem Karnym w Gdańsku, na ławie oskarżonych zasiadło 15 osób, w tym 5 kobiet ${ }^{27}$. Skład sądu stanowili: doktor Józef Tarczyński — przewodniczący; redaktor Józef Lżycki i profesor Tadeusz Tylewski — ławnicy. Na karę śmierci skazano: Johanna Paulusa — członka kierownictwa obozu w Stutthofie i komendanta obozu w Wyślinkach; Józefa Reitera - kapo obozowego; Wacława Kowalskiego - kapo obozowego; Wandę Klaff, Gerdę Steinhoff, Elizabeth Becker, Ewę Paradis i Jenny Wandę Barkmann — strażniczki bloków kobiecych; Jana Braita — lekarza obozowego, a także Tadeusza Kopczyńskiego i Franciszka Szopińskiego. Po negatywnym rozpatrzeniu próśb o ułaskawienie przez przewodniczącego Krajowej Rady Narodowej Bolesława Bieruta wszyscy zostali straceni publicznie przez powieszenie 4 lipca 1946 roku w Gdańsku. Wyroki śmierci wykonywali byli więźniowie obozów koncentracyjnych lub członkowie ich rodzin, ubrani w obozowe ubrania (tak zwane pasiaki), wśród nich była jedna kobieta - wszyscy zgłosili się ochotniczo do pełnienia funkcji katów ${ }^{28}$.

Sądy specjalne efektywnie wykorzystywały swoje kompetencje również w ramach procedur ekstradycyjnych podejrzanych o zbrodnie popełnione na ziemiach polskich. Od 22 lipca 1944 roku do 22 lipca 1946 roku Polska zgłosiła 8413 wniosków o ekstradycję, z których 7405 wpisano do rejestru Komisji Zjednoczonych Narodów do spraw Zbrodni Wojennych. W okresie między kwietniem 1946 roku a grudniem 1950 roku Polska Misja Wojskowa Badania Niemieckich Zbrodni Wojennych podjęła starania zakończone wydaniem 1803 podejrzanych o zbrodnie wojenne, z których około $80 \%$ otrzymało wyroki skazujące; z amerykańskiej strefy okupacyjnej Niemiec pochodziło 1325 osób, z brytyjskiej - 392 osoby, z radzieckiej - 51 osób, a z francuskiej - 35 osób $^{29}$. Specjalne sądy karne zostały zniesione na mocy dekretu o zniesieniu specjalnych sądów karnych z dnia 17 października 1946 roku, a ich kompetencje przejęły właściwe sądy okręgowe ${ }^{30}$.

W świetle powyższego uprawniony jest pogląd, że dekret i powołane do egzekwowania jego przepisów karnych sądownictwo specjalne spełniło swoje zadanie w zakresie ścigania i karania osób, które podczas niemieckiej okupacji ziem polskich w latach II wojny światowej realizowały ludobójcze założenia narodowosocjalistycznego antysemityzmu oraz antypolonizmu. Należy podkreślić, że pomimo niespotykanej wcześniej w polskim porządku prawnym represyjności dekret był stosowany przez składy orzekające przygotowane merytorycznie do wymiaru sprawiedliwości, w tym prawników - praktyków wykształconych w tym zakresie przed wybuchem II wojny światowej. Represyjność dekretu, bezwzględnie oznaczona sankcja w postaci kary śmierci za zbrodnie określone w przepisach jego

27 Z. Biegański, op. cit., s. 190.

28 Ibidem.

29 L. Szpak, Ekstradycja hitlerowskich zbrodniarzy wojennych ze szczególnym uwzględnieniem praktyki polskiej, Warszawa 1979, s. 25.

30 Dz.U. z 1946 r. Nr 59, poz. 324. 
art. 1, wreszcie surowość kary dodatkowej konfiskaty mienia - wszystkie te regulacje nie odbiegały zasadniczo od niemal powszechnie wówczas akceptowanych reguł karania zbrodniarzy hitlerowskich, których wyrazem stał się wyrok skazujący Międzynarodowego Trybunału Wojskowego (Trybunału Norymberskiego). Rozmiar i skala zbrodni niemieckich narodowych socjalistów, których dopuścili się na ziemiach polskich (Generalne Gubernatorstwo, ziemie wcielone do III Rzeszy) zbrodni bez precedensu, musiały zostać odpowiednio napiętnowane, a ich sprawcy ukarani z pełną bezwzględnością prawa. Co więcej, właśnie przez represyjność regulacji dekretu, czyniących zadość społecznemu oczekiwaniu bezwzględnej rozprawy z hitlerowskimi ludobójcami i zbrodniarzami, nie dochodziło do wybuchów społecznego niezadowolenia, z którym musiałaby liczyć się nawet nowa, totalitarna władza instalująca się na ziemiach polskich od lipca 1944 roku. Dowodzi tego chociażby proces Rudolfa Hössa i trzymanie daty jego egzekucji w tajemnicy w celu uniknięcia rozruchów i docelowo linczu byłego komendanta KL Auschwitz z rąk żądnych odwetu polskich mieszkańców Oświęcimia.

\section{Społeczne aspekty stosowania dekretu}

Szczególne emocje w społeczeństwie budził proces byłego gauleitera oraz namiestnika Kraju Warty Arthura Greisera (1897-1946), co znajduje odzwierciedlenie w ówczesnych relacjach prasowych. Wśród Polaków przeważały opinie, iż prace Trybunału Norymberskiego, z powodu udziału sędziów angielskich i amerykańskich jako reprezentujących nacje niedoświadczone skutkami zbrodniczej polityki III Rzeszy, nie doprowadzą do sprawiedliwego, surowego ukarania sądzonych tam zbrodniarzy hitlerowskich. Wskazane nastroje społeczne umiejętnie wykorzystały władze komunistyczne, dążąc do osądzenia Arthura Greisera w Polsce.

Związek Byłych Więźniów Politycznych w Poznaniu (dalej też: związek) zwołał na tamtejszym Placu Wolności 9 grudnia 1945 roku wiec, którego celem było wyrażenie masowego społecznego protestu przeciwko zbyt łagodnemu traktowaniu ujętych zbrodniarzy hitlerowskich ${ }^{31}$. Tydzień później na Uniwersytecie Poznańskim związek zorganizował kolejny wiec, podczas którego jego prezes Jan Świstalski w nacechowanym emocjonalnie, pełnym oburzenia wystąpieniu skrytykował pobłażliwość wobec niemieckich „katów i zbrodniarzy”; odwołał się nawet do czasów zwycięstwa pod Grunwaldem w 1410 roku, wskazując, iż nie można ulegać jakimkolwiek zewnętrznym naciskom, które uniemożliwiłyby powtórzenie błędu wiktorii grunwaldzkiej i niewykorzystanie w pełni owoców zwycięstwa. Co więcej, prezes Świstalski stwierdził, że litość okazana Niemcom może doprowadzić do tego, że za dwadzieścia-trzydzieści lat wywołają kolejną

31 Jutro wiec protestacyjny, „Głos Wielkopolski” 8.12.1945, cyt. za: M. Przybylski, Publiczna egzekucja Arthura Greisera w poznańskiej prasie, [w:] Media wobec śmierci, t. 1, red. K. Kwasik, J. Jaroszyński, G. Łęcicki, Warszawa 2012, s. 122. 
wojnę. Na zakończenie wiecu, deklarując działanie w imieniu społeczności byłego Kraju Warty, podjęto rezolucję, w której zażądano między innymi, aby oskarżonych o zbrodnie hitlerowskie sądzili byli więźniowie polityczni, oskarżonym tym odebrano prawo korzystania z pomocy prawnej niemieckich adwokatów (którzy sami powinni zasiąść na ławach oskarżonych), a proces Arthura Greisera odbył się w Polsce ${ }^{32}$. W działaniach związku nie sposób jednak dopatrywać się realizacji nieskrępowanej i niezależnej od czynników oficjalnej władzy inicjatywy społecznej. Przyjęcie takiego stanowiska nie uwzględnia bowiem takich okoliczności jak postępujący totalitarny charakter władzy komunistycznej, dążącej do kontroli wszelkich przejawów masowych akcji społecznych, czy członkostwa w związku takich osób jak Henryk Świątkowski i Józef Cyrankiewicz (od 1946 roku stojący na czele związku).

Już po sprowadzeniu Greisera do Polski na poznańskim placu Wolności 31 marca 1946 roku odbyła się manifestacja miejscowej ludności, podczas której poruszono między innymi sprawę jego osądzenia w Poznaniu. W podjętej rezolucji skierowanej do władz polskich określono Greisera chociażby jako „krwawego kata ludu wielkopolskiego"; uznano ponadto, iż proces norymberski dotyczy całego narodu niemieckiego jako odpowiedzialnego za zbrodnie hitlerowskie, natomiast Arthur Greiser jako jeden z największych zbrodniarzy tego narodu powinien być osądzony publicznie przed sądem polskim i publicznie ukarany.

W kontekście zainteresowania procesem Greisera kontrolowana przez władze komunistyczne prasa informowała społeczeństwo polskie - w sposób przejaskrawiony i nasycony brutalnym językiem — jak oskarżony spędza czas w areszcie. Był przedstawiany między innymi jako: „kandydat do poprzecznej belki”, „,kupczyk niewielkiego kalibru o wrodzonym okrucieństwie i cofniętym w tył czole, które nadawać miało jego rysom cech zbrodniczych”, „silnych, włochatych rękach o krótkich i tępych palcach, świadczących jednoznacznie o instynktach mordercy"33.

Datę rozpoczęcia procesu Arthura Greisera w Poznaniu wyznaczono na 21 czerwca 1946 roku. Władzom polskim bardzo zależało na wzmożeniu, i tak olbrzymiego, społecznego zainteresowania postępowaniem. Na salę rozpraw (przeznaczono na ten cel aulę liczącą około 750 miejsc) wydawano specjalne bilety, a przebieg procesu miał być thumaczony na języki: angielski, rosyjski i francuski. W prasie pojawiły się także, zgodnie ze społecznymi oczekiwaniami, publicystyczne ,akty oskarżenia”. Szczególnie emocjonalny wydźwięk miał utrzymany w takiej konwencji artykuł Jana Brzeskiego ${ }^{34}$. Polskim władzom zależało również na akcentowaniu zapewniania Greiserowi prawa do obrony w toku procesu. Reprezentowało go dwóch znanych przedstawicieli palestry: doktorzy Stanisław Hejmowski i Jan Kręglewski.

32 Ibidem.

33 Kandydaci do poprzecznej belki Greiser i Fischer, „Głos Wielkopolski” 4.05.1946, cyt. za: M. Przybylski, op. cit., s. 125.

34 Sprawiedliwość zwycięża, „Głos Wielkopolski” 16.06.1946, cyt. za: M. Przybylski, op. cit., s. 126. 
Przed rozpoczęciem rozprawy przed salą sądową odbyła się demonstracja zorganizowana przez Polską Partię Robotniczą i Polską Partię Socjalistyczną pod hasłem „Nie będzie Greiser pluł nam w twarz”. Prasa zachęcała, aby uczestniczył w niej każdy obywatel Poznania ${ }^{35}$. W demonstracji brał udział między innymi Henryk Świątkowski, ówczesny minister sprawiedliwości. Przebieg rozprawy sądowej był transmitowany nie tylko w masowo wykupowanej prasie wielkopolskiej, lecz także z wykorzystaniem transmisji radiowej. Obecna na sali sądowej polska publiczność niejednokrotnie reagowała groźnymi pomrukami dezaprobaty, a nawet wybuchami szyderczego śmiechu, słysząc nieudolne tłumaczenia oskarżonego Greisera, usiłującego usprawiedliwić swoje postępowanie.

Szczególnie wiele miejsca prasa wielkopolska poświęciła ogłoszeniu wyroku skazującego Arthura Greisera na karę śmierci, a następnie wyczekiwaniu na termin jego egzekucji ${ }^{36}$. Nadzwyczajne wydanie „Głosu Wielkopolskiego”, które ukazało się 20 lipca 1946 roku wraz ze specjalnie wydrukowanymi na tę okoliczność plakatami, informowało, iż Arthur Greiser zostanie publicznie stracony przez powieszenie 21 lipca 1946 roku o godzinie 7:00 na stokach poznańskiej cytadeli. Zachęcano prawie każdego do obejrzenia egzekucji, wzywając jednocześnie do zachowania powagi. Szczegółowo przedstawiano również procedurę egzekucji ${ }^{37}$. O jej szczegółowym przebiegu, a nawet postąpieniu z ciałem straconego skazanego, również pisano; co więcej, egzekucja Arthura Greisera została sfilmowana, relacjonowano ją też przez radio. Należy podkreślić, że sprawozdania prasowe skwapliwie pominęły milczeniem niefrasobliwość kata przy wykonaniu wyroku (istnieje podejrzenie, iż z powodu źle dobranej długości sznura Greiser zmarł wskutek zwielokrotniającego jego cierpienie duszenia, nie zaś wskutek właściwego dla egzekucji przez powieszenie szybkiego zerwania rdzenia kręgowego; ponadto tuż przed założeniem pętli zamaskowany kat okazywał gesty świadczące o wyraźnej satysfakcji z wykonywania wyroku).

\section{Przeciwko polskiemu podziemiu antykomunistycznemu}

Jak każda władza totalitarna również polskie władze komunistyczne, instalowane dzięki poparciu politycznemu i militarnemu ZSRR, instrumentalnie traktowały prawo, w tym dekret sierpniowy. Względnie szybko okazało się, że może on stanowić, przez represyjność swoich regulacji, nie tylko instrument wymiaru sprawiedliwości wobec rzeczywistych nazistowskich zbrodniarzy oraz

35 Potepiamy zbrodnicza działalność Greisera, „Głos Wielkopolski” 21.06.1946, cyt. za: M. Przybylski, op. cit., s. 127.

36 Kiedy Greiser zawiśnie na szubienicy, „Głos Wielkopolski” 17.07.1946, cyt. za: M. Przybylski, op. cit., s. 130.

37 Jutro o godz.7 rano Greiser zawiśnie na szubienicy, „Głos Wielkopolski” 20.07.1946, cyt. za: M. Przybylski, op. cit., s. 131. 
kolaborantów, lecz także przeciwników politycznych nowej władzy — członków szeroko pojmowanego polskiego podziemia antykomunistycznego.

Jakkolwiek przewaga militarna nowej władzy (dzięki wsparciu ze strony ZSRR) wobec polskiego podziemia antykomunistycznego była przygniatająca, a zwycięstwo militarne pewne, szczególnie pożądane przez władze komunistyczne było zohydzenie byłych żołnierzy formacji niepodległościowych w oczach polskiej opinii publicznej. Miało to służyć również legitymizacji nowej władzy i pozyskaniu przez nią społecznej przychylności przy jednoczesnym stygmatyzowaniu żołnierzy podziemia antykomunistycznego jako hitlerowskich kolaborantów. W tym celu wykorzystywano właśnie karnoprawne regulacje dekretu. Uprawniony jest zatem prezentowany w piśmiennictwie pogląd, że „Było to oskarżenie perfidne, okrutne i groźne w swych konsekwencjach, pozbawiało bowiem dawnych żołnierzy Państwa Podziemnego zaszczytnego miana obrońców Ojczyzny i narażało na drakońskie kary"38.

Po raz pierwszy oficjalne - chociaż jeszcze w wymiarze moralno-politycznym, a nie prawnym - oskarżenie o kolaborację z III Rzeszą pod adresem polskiego rządu na uchodźstwie oraz struktur Polskiego Państwa Podziemnego padło przy okazji odkrycia przez Niemców mogił polskich jeńców wojennych pomordowanych w Katyniu (kwiecień 1943 roku). W moskiewskiej gazecie „Prawda”, stanowiącej oficjalny prasowy organ WKP(b), 19 kwietnia 1943 roku ukazała się odpowiedź władz sowieckich na zwrócenie się przez III Rzeszę oraz rząd generała Władysława Sikorskiego do Międzynarodowego Czerwonego Krzyża w sprawie wskazanego odkrycia dokonanego przez Niemców. Na łamach „Prawdy” napisano wówczas o „polskich współpracownikach Hitlera”, a w nocie wręczonej przez rząd sowiecki polskiemu ambasadorowi w Moskwie nocą z 25 na 26 kwietnia 1943 roku znalazło się oskarżenie, że „między wrogiem sprzymierzonych - Hitlerem - a Rządem Polskim istnieje kontakt i zmowa" ${ }^{39}$. Nieco później, bo w maju 1943 roku, pisząc list do Churchilla, Stalin określił otoczenie rządu polskiego mianem ,prohitlerowskich krzykaczy”. Mając tak przygotowany polityczny „grunt”, polscy komuniści mogli przystąpić do działań represyjnych, wykorzystując $\mathrm{w}$ tym celu narzędzia prawne, którymi dysponowali.

$\mathrm{Z}$ uwagi na sygnalizowane już ograniczenia objętościowe niniejszego opracowania niemożliwe jest przedstawienie wszystkich lub chociażby najbardziej reprezentatywnych przypadków ewidentnego nadużywania dekretu i skazywania z jego mocy przedstawicieli struktur Polskiego Państwa Podziemnego. Za wystarczające należy uznać odwołanie się do procesu i skazania generała Augusta Emila Fieldorfa (konspiracyjny pseudonim „Nil”). W trakcie procesu, który zasługuje

38 J. Wróbel, M. Słojewski, Zbrodnie sądowe z oskarżenia o kolaborację z nazistami. Procesy kierownictwa PKB, ,Startu” i Okręgowego KWP przed Sąem Wojewódzkim w Warszawie, [w:] Przestępstwa sędziów i prokuratorów w Polsce lat 1944-1956, red. W. Kulesza, A. Rzepliński, Warszawa 2001, s. 85-86.

39 Ibidem, s. 88. 
na miano mordu sądowego, zarzucono mu „pójście na rękę” niemieckim okupantom przez zwalczanie takich organizacji, jak Polska Partia Robotnicza, Gwardia Ludowa i Armia Ludowa. Pomimo brutalnych metod śledztwa, w tym tortur psychicznych (podanie nieprawdziwej informacji o aresztowaniu żony i dzieci), generał Fieldorf konsekwentnie nie przyznał się do zarzuconych mu czynów, odmówił również współpracy (w tym przez wydanie odezwy do byłych żołnierzy Armii Krajowej, którzy mieliby się ujawnić wobec władzy komunistycznej). Wyrok skazujący generała na karę śmierci przez powieszenie zapadł 16 kwietnia 1952 roku, wydany przez Sąd Wojewódzki dla miasta stołecznego Warszawy. Został on utrzymany w mocy przez Sąd Najwyższy, a Rada Państwa nie skorzystała z prawa łaski. Wyrok wykonano 24 lutego 1953 roku $^{40}$.

\section{Zakończenie}

W pierwszej kolejności należy zwrócić uwagę na swoisty sposób zredagowania samego tytułu dekretu - akt prawny wymierzony był przede wszystkim przeciwko „faszystowsko-hitlerowskim zbrodniarzom”. Tymczasem za nieprawidłowe trzeba uznać kwalifikowanie ustroju społeczno-politycznego III Rzeszy Adolfa Hitlera jako faszyzmu. Niemiecki narodowy socjalizm wykazywał bowiem wiele odmienności od włoskiego faszyzmu, eksponując w szczególności skrajny antysemityzm oraz rasizm, niewystępujące w doktrynie faszystowskiej. Taki sposób zredagowania tytułu można thumaczyć charakterystycznym dla sowieckiego kursu politycznego unikaniem wykazania chociażby językowych podobieństw między socjalizmem budowanym w ZSRR a narodowym socjalizmem III Rzeszy. Dążenie do piętnowania jako „faszystów” wszystkich ideologicznych przeciwników ZSRR było bowiem prezentowane w propagandzie sowieckiej już od lat dwudziestych XX wieku.

Niemiecki narodowy socjalizm odcisnął szczególne piętno na ziemiach polskich w okresie II wojny światowej. Zwycięstwo III Rzeszy nad Polską jesienią 1939 roku, jak też późniejsze sukcesy wojsk niemieckich, dały nazistom szansę stosowania nieskrępowanej przemocy wobec wyjętych poza nawias człowieczeństwa, skazanych na całkowitą eksterminację Żydów. Z kolei nazistowski antypolonizm dyktował biologiczne wyniszczenie polskiej inteligencji i traktowanie pozostałych Polaków jako ,podludzi”, przeznaczonych do stopniowej eksterminacji lub pełnienia funkcji ludności służebnej wobec „wyższych rasowo” Niemców. Założenia te były w pełni realizowane przez hitlerowski aparat terroru, którego bestialską emanację stanowił system niemieckich obozów koncentracyjnych oraz niemieckich obozów zagłady zlokalizowanych na ziemiach polskich.

40 Zob. https://www.polskieradio.pl/39/156/Artykul/788049,Gen-August-Emil-Fieldorf-Nilwierny-zolnierz-Niepodleglej (dostęp: 20.11.2018). 
Nowa władza komunistyczna, zainstalowana w Polsce wyłącznie dzięki politycznej i militarnej protekcji ZSRR, bezzwłocznie przystąpiła do realizacji działań zmierzających do ugruntowania swojej pozycji. Jednym z nich było wdrożenie przepisów prawa odwetowego, ukierunkowanego na surowe ukaranie sprawców realizujących na ziemiach polskich ludobójczą politykę III Rzeszy. Takie działanie z pewnością miało na celu również pozyskanie polskiego społeczeństwa, którego przedstawiciele byli przez hitlerowców rozstrzeliwani w Palmirach, katowani na Pawiaku czy mordowani w Oświęcimiu. Uprawnione będzie przyjęcie, że antynazizm i dokonanie surowego rozliczenia zbrodniarzy hitlerowskich stały się jednymi z fundamentalnych założeń budowania w Polsce nowego ustroju. Towarzyszyło temu lansowanie poglądu, iż zwycięstwo „nad faszyzmem” (w istocie: niemieckim narodowym socjalizmem) możliwe było wyłącznie dzięki militarnemu zaangażowaniu się ZSRR i tylko sowiecki komunizm był w stanie zwalczyć hitleryzm. $Z$ czasem podjęto także działania ukierunkowane na wykazanie pozorności walki struktur politycznych Polskiego Państwa Podziemnego (związanych z polskim rządem emigracyjnym), a nawet ich kolaboracji z hitlerowcami. Celem tych działań było wytworzenie w społeczeństwie polskim przekonania, że wyłącznie nowa władza komunistyczna jest gwarantem sprawiedliwego ukarania zbrodniarzy i dokonania prawidłowego rozrachunku z nazizmem.

Społeczeństwo polskie w zdecydowanej większości podzielało pogląd surowego ukarania funkcjonariuszy hitlerowskiego aparatu terroru funkcjonującego w okupowanej przez Niemców Polsce. Władze komunistyczne w pełni wykorzystały społeczne oczekiwania w tym zakresie. Był to zapewne jedyny przykład tak daleko idącego zrozumienia oczekiwań społecznych i ich realizacji przez polskich komunistów po objęciu przez nich władzy w naszym kraju. Konsekwentna polityka polskiego wymiaru sprawiedliwości w zakresie ścigania i surowego karania hitlerowskich zbrodniarzy realizowała postulat silnych w polskim społeczeństwie okresu powojennego antyniemieckich reminiscencji i dążeń odwetowych. W oczywisty sposób służyło to legalizacji politycznego bytu nowej władzy w świadomości Polaków, jej legitymizacji jako „depozytariusza krzywd”, sprawiedliwego, „ludowego sędziego”, pozbawionego litości, ale jednocześnie respektującego reguły procedowania ukształtowane praktyką Trybunału Norymberskiego. Praktyce wymiaru sprawiedliwości towarzyszyło też aktywizowanie przez władzę komunistyczną i osobiste zaangażowanie jej prominentnych przedstawicieli w eskalowanie społecznego poczucia krzywdy i sprawiedliwej, surowej odpłaty za nazistowskie zbrodnie. Dowodzi tego udział wysokich przedstawicieli władz komunistycznych w masowych manifestacjach (organizowanych również przy wydatnym udziale i wsparciu czynników rządowych) towarzyszących ściganiu i ukaraniu Arthura Greisera. Casus Greisera wskazuje ponadto, jak wielką rolę odegrała w oddziaływaniu na opinię publiczną prasa, kontrolowana przez oficjalne komunistyczne czynniki polityczne. Relacje prasowe z przewodu sądowego szczegółowe, utrzymane często w stylu dehumanizacji osoby oskarżonego, jego 
zohydzenia, a wręcz ukazania go jako przykładu urodzonego „człowieka-zbrodniarza" - padały na podatny społecznie grunt. Szczególne staranie, aby procesowi Arthura Greisera nadać możliwie najdalej idący wymiar jawności i udziału publiczności, oraz jego relacjonowana w mediach, publiczna egzekucja miały stanowić manifestację surowej sprawiedliwości i niepobłażania „krwawemu katowi ludu wielkopolskiego".

Regulacje karnoprawne dekretu sierpniowego (również w brzmieniu nadanym przez kolejne jego nowelizacje), jakkolwiek bardzo represyjne, nie odbiegały od międzynarodowych, powszechnie aprobowanych standardów wypracowanych w toku działalności Trybunału Norymberskiego. Dotyczy to zarówno kwestii naruszenia zagadnienia retroakcji prawa karnego oraz faktycznego sprowadzenia kary śmierci do funkcji podstawowego środka karnoprawnej reakcji. Sądownictwo specjalne, którego kognicji powierzono sprawy osób oskarżonych o czyny przewidziane w dekrecie, sprawnie realizowało swoje kompetencje, skutecznie ścigając zbrodniarzy hitlerowskich, w tym tych znajdujących się poza obszarem podlegającym władzy państwowej polskich komunistów. Wymierzana im kara śmierci była wykonywana przez powieszenie, bezzwłocznie, nierzadko publicznie, co stanowiło efektywny sposób upowszechniania w świadomości społecznej przekonania o skuteczności i nieuchronności sprawiedliwej odpłaty za zbrodnie popełnione na obywatelach polskich. Obecnie, gdy ustawodawstwa europejskie niemal całkowicie odrzuciły stosowanie kary śmierci, taka praktyka może zostać uznana za szokującą. Niemniej jednak wówczas, gdy dominowały żądania „rozprawienia się” $\mathrm{z}$ hitlerowskimi zbrodniarzami, tylko taka treść prawa i forma jego egzekwowania były odpowiednie. Nie należy bowiem kiedykolwiek pomijać tego, iż oskarżonymi byli ludzie, którzy nierzadko z poczuciem satysfakcji wykorzystywali cząstkę władzy, jaką powierzył im hitlerowski aparat terroru, aby masowo mordować Żydów, bez zastanowienia zabijać Polaków, torturować ich, znęcać się nad nimi i odzierać ich z godności.

Dekret został również wykorzystany do walki z przeciwnikami nowej komunistycznej władzy — byłymi żołnierzami Polskiego Państwa Podziemnego. Sfingowane procesy sądowe, podczas których oskarżano byłych żołnierzy AK o ,pójście na rękę" niemieckim władzom okupacyjnym, nie miały niczego wspólnego z procedurą sądową - były zinstytucjonalizowaną formą morderstwa dokonywanego na niewinnych ludziach, wyznających wartości obce tym, którzy ich oskarżali, skazywali i uśmiercali. Na gorzki paradoks zakrawa to, iż polscy patrioci byli faktycznie pozbawiani prawa do obrony w toku takich „procesów”, które to prawo respektowano wobec rzeczywistych zbrodniarzy hitlerowskich. Co więcej, organy śledcze nie wahały się w takich przypadkach szantażować oskarżonych, niewinnych ludzi, że w wypadku nieprzyznania się do winy zostanie im ona udowodniona w drodze uciekania się do stworzenia fałszywych jej dowodów, w tym przez współpracę funkcjonariuszy organów śledczych $\mathrm{z}$ osadzonymi w polskich więzieniach byłymi gestapowcami. Stanowiło to nie tylko zaprzeczenie 
sprawiedliwości, ale dawało jednoznaczny wyraz totalitarnego bezprawia, czerpiącego inspiracje z modelu stalinowskiego procesu pokazowego, wypracowanego jeszcze w połowie lat trzydziestych XX wieku w ZSRR. Również w tym wypadku, podobnie jak miało to miejsce wobec faktycznych przedstawicieli aparatu terroru III Rzeszy, polskie władze komunistyczne sięgały do instrumentów propagandowych, tak aby przedstawić żołnierzy podziemia antykomunistycznego jako hitlerowskich kolaborantów i antypolskich zdrajców. Działanie to miało na celu ich oczernienie, zohydzenie, delegitymizację tego, co tradycyjnie wiąże się z polskim etosem żołnierza walczącego o wolność ojczyzny. Dowodzi tego sądowe morderstwo generała Augusta Emila Fieldorfa.

Wreszcie należy podkreślić, iż na podstawie dekretu nie zostały postawione w stan oskarżenia, skazane i surowo ukarane osoby, które działając na rzecz ZSRR (państwa sprzymierzonego wszak z III Rzeszą od podpisania paktu Ribbentrop-Mołotow w sierpniu 1939 roku do wybuchu wojny niemiecko-sowieckiej w czerwcu 1941 roku), aktywnie uczestniczyły w czynach wyczerpujących znamiona zbrodni określonych przepisami dekretu z pokrzywdzeniem obywateli polskich.

\section{Bibliografia}

\section{Literatura}

Biegański Z., Kara śmierci w orzecznictwie Specjalnych Sąów Karnych w Polsce (1944-1946), „Echa Przeszłości” 2004, nr 5.

Dubel L., Kostrubiec J., Ławnikowicz G., Markwart Z., Elementy nauki o państwie i polityce, Warszawa 2011.

Kładoczny P., Prawo jako narzędzie represji w Polsce Ludowej (1944-1956), Warszawa 2004.

Kobierska-Motas E., Ekstradycja przestępców wojennych do Polski z czterech stref okupacyjnych Niemiec 1946-1950, cz. 2, Warszawa 1992.

Lityński A., Ze studiów nad początkami wojskowego prawa karnego PRL, [w:] Problemy prawa karnego, t. 21, red. K. Marszał, Katowice 1995.

Murzynowski A., Rezler J., Wymiar sprawiedliwości w Polsce w latach 1944-1970. Ustawodawstwo, organizacja i działalność, Warszawa 1972.

Pasek A., Przestepstwa okupacyjne w polskim prawie karnym z lat 1944-1956, Wrocław 2002.

Przybylski M., Publiczna egzekucja Arthura Greisera w poznańskiej prasie, [w:] Media wobec śmierci, t. 1, red. K. Kwasik, J. Jaroszyński, G. Łęcicki, Warszawa 2012.

Szpak L., Ekstradycja hitlerowskich zbrodniarzy wojennych ze szczególnym uwzględnieniem praktyki polskiej, Warszawa 1979.

Wróbel J., Słojewski M., Zbrodnie sądowe z oskarżenia o kolaborację z nazistami. Procesy kierownictwa PKB, ,,Startu” i Okręgowego KWP przed Sądem Wojewódzkim w Warszawie, [w:] Przestępstwa sędziów i prokuratorów w Polsce lat 1944-1956, red. W. Kulesza, A. Rzepliński, Warszawa 2001. 


\section{Orzecznictwo}

Uzasadnienie wyroku Sądu Apelacyjnego we Wrocławiu z dnia 14 stycznia 1950 roku, sygn. akt III K 82/50, APW-Prok.Woj. 857/15, s. 7.

Uzasadnienie wyroku Sądu Apelacyjnego we Wrocławiu z dnia 23 czerwca 1950 roku, sygn. akt III K 82/50, APW-Prok.Woj. 863/15, s. 21.

Uzasadnienie wyroku Sądu Najwyższego z dnia 13 lutego 1948 roku, sygn. akt Kr K 33/48, Zb.Orz. $44 / 48$.

Uzasadnienie wyroku Sądu Najwyższego z dnia 8 kwietnia 1948 roku, sygn. akt Wa K 101/48, Zb.Orz. 103/48.

Uzasadnienie wyroku Sądu Najwyższego z dnia 29 sierpnia 1948 roku, sygn. akt Wa K 338/48, DPP 1948, nr 9, s. 47-48.

Uzasadnienie wyroku Sądu Najwyższego z dnia 1 października 1948 roku, sygn. akt Kr K 1254/48, „Państwo i Prawo” 1948, nr 12, s. 151.

Uzasadnienie wyroku Sądu Najwyższego z dnia 25 maja 1949 roku, sygn. akt K/478/49, „Państwo i Prawo" 1949, nr 9-10, s. 196.

Uzasadnienie wyroku Sądu Najwyższego z dnia 8 sierpnia 1950 roku, sygn. akt K 454/50, „Państwo i Prawo" 1950, nr 11, s. 192-193.

\section{Akty prawne}

Dekret Polskiego Komitetu Wyzwolenia Narodowego z dnia 31 sierpnia 1944 roku o wymiarze kary dla faszystowsko-hitlerowskich zbrodniarzy winnych zabójstw i znęcania się nad ludnością cywilną i jeńcami oraz dla zdrajców Narodu Polskiego (Dz.U. z 1946 r. Nr 69, poz. 376).

Dekret Polskiego Komitetu Wyzwolenia Narodowego z dnia 12 września 1944 roku o specjalnych sądach karnych dla spraw zbrodniarzy faszystowsko-hitlerowskich (Dz.U. z 1944 r. Nr 4, poz. 21).

Dekret Rady Ministrów z dnia 22 stycznia 1946 roku o Najwyższym Trybunale Narodowym (Dz.U. z 1946 r. Nr 59, poz. 326-327).

Dekret z dnia 17 października 1946 roku o zniesieniu specjalnych sądów karnych (Dz.U. z 1946 r. Nr 59, poz. 324).

Porozumienie międzynarodowe w przedmiocie ścigania i karania głównych przestępców wojennych Osi Europejskiej, podpisane w Londynie dnia 8 sierpnia 1945 roku (Dz.U. z 1947 r. $\mathrm{Nr}$ 63, poz. 367).

Rozporządzenie Prezydenta Rzeczypospolitej z dnia 11 lipca 1932 roku Kodeks karny (Dz.U. z 1932 r. Nr 60, poz. 571).

\section{Źródła internetowe}

https://www.polskieradio.pl/39/156/Artykul/788049, Gen-August-Emil-Fieldorf-Nil-wiernyzolnierz-Niepodleglej. 
THE PKWN AUGUST DECREE OF 1944 AS AN INSTRUMENT FOR LEGALIZING THE COMMUNIST AUTHORITIES IN POLAND

\section{Summary}

The aim of this study is to present the key assumptions and practices of the August Decree of 31 August 1944 of the Polish Committee of National Liberation (PKWN). It is important to show how the Decree was an instrument for the settlement of Nazi crimes in Poland, and to what extent a tool to defeat the opponents of communist rule in Poland. The most important goal of the work is to show how instrumental treatment of the law served the legitimization of power: unwanted, deprived of broader social support, based solely on the violence and military strength of the Soviet Union.

Principles and legal regulations of the Decree will be discussed as well as its practical application in the jurisprudence of special and common courts.

Keywords: Nazi crimes in Poland, political repression, special judiciary, the death penalty.

Marcin Birt

marcin.birt@uwr.edu.pl 